\title{
ORIGINAL ARTICLE IL28B genetic variations are associated with high sustained virological response (SVR) of interferon- $\alpha$ plus ribavirin therapy in Taiwanese chronic HCV infection
}

\author{
J-Y Chen ${ }^{1}$, C-Y Lin ${ }^{2}$, C-M Wang ${ }^{3}$, Y-T Lin ${ }^{1}$, S-N Kuo ${ }^{1}$, C-F Shiu ${ }^{4}$, S-W Chang ${ }^{4}$, J Wu ${ }^{5}$ and I-S Sheen ${ }^{2}$ \\ ${ }^{1}$ Department of Medicine, Division of Allergy, Immunology and Rheumatology, Chang Gung Memorial Hospital, Chang Gung \\ University College of Medicine, Taiwan, Republic of China; ${ }^{2}$ Department of Medicine, Division of Hepatology and Gastroenterology, \\ Chang Gung Memorial Hospital, Chang Gung University College of Medicine, Taiwan, Republic of China; ${ }^{3}$ Department of \\ Rehabilitation, Chang Gung Memorial Hospital, Chang Gung University College of Medicine, Taiwan, Republic of China; ${ }^{4}$ Division of \\ Biostatistics, Institute of Biomedical Sciences, Academia Sinica, Taipei, Taiwan, Republic of China and ${ }^{5}$ Department of Veterinary and \\ Biomedical Sciences, University of Minnesota, St Paul, MN, USA
}

\begin{abstract}
Chronic hepatitis $C$ virus (HCV) infection patients exhibit different sustained virological responses (SVRs) following the treatment with pegylated interferon- $\alpha$ (IFN- $\alpha$ ) and ribavirin. Genome-wide association studies consistently linked SVR of IFN- $\alpha-$ based therapy to the IL28B single-nucleotide polymorphisms (SNPS) on chromosome 19q.13 in various populations. This study was undertaken to investigate the association of IL28B SNPS with SVR in a cohort of Taiwanese chronic HCV patients. Ten SNPS of IL28B were genotyped in 728 chronic HCV patients and 960 healthy controls. Genotype distributions, allele frequencies and haplotypes were tested for SVR and susceptibility in Taiwanese chronic HCV patients. Non-genotype 1 infection (adjusted $P=3.3 \times 10^{-12}$, odds ratio (OR) 0.179 ; 95\% confidence interval (Cl): 0.110-0.290) and low HCV viral load $\left(<400000 \mathrm{IU} \mathrm{m}^{-1}\right)$ (adjusted $P=3.5 \times 10^{-9}$, OR 0.299; 95\% Cl: 0.200-0.446) were two major factors identified for high SVR. Notably, eight IL28B SNPs including previously described disease-associated SNPs (Trend test $P=0.005)$ were significantly associated with SVR. Our data indicate that IL28B polymorphisms are the essential contributing factors for high SVR in Taiwanese chronic HCV patients. Combination of virus genotyping and host genetic data may be used to select the optimal treatment regimes in IFN-based therapy.
\end{abstract}

Genes and Immunity (2011) 12, 300-309; doi:10.1038/gene.2011.1; published online 24 February 2011

Keywords: hepatitis $C$; sustained virological response; IL28B; single-nucleotide polymorphisms

\section{Introduction}

Hepatitis C virus (HCV) infection, the leading cause of chronic liver disease, is emerging as a global concern of public health inflicting up to $3 \%$ human populations. ${ }^{1} \mathrm{HCV}$ infection usually appears as an asymptomatic disease, which accompanies the development of chronic persistent viremia in majority individuals despite substantial virus and host cellular immune responses.. ${ }^{2-4} \mathrm{HCV}$ chronic infection associates with an intra-hepatic inflammatory infiltration, which is frequently followed by progressive fibrosis that leads to liver cirrhosis and ultimately to the development of hepatocellular carcinoma..$^{5-7}$

Correspondence: Professor I-S Sheen, Department of Medicine, Division of Hepatology and Gastroenterology, Chang Gung Memorial Hospital, Chang Gung University College of Medicine, Taiwan, Republic of China.

E-mail: issheen.jks@gmail.com or Dr J-Y Chen, Division of Allergy, Immunology and Rheumatology, Department of Medicine, Chang Gung Memorial Hospital, Chang Gung University College of Medicine, No. 5, Fu-Shin Street Kuei-Shan, Tao-Yuan, Taiwan, Republic of China.

E-mail: jychen31@adm.cgmh.org.tw

Received 17 May 2010; revised and accepted 10 August 2010; published online 24 February 2011
$\mathrm{HCV}$ infection induces the production of interferons (IFNs), especially IFN $\alpha$ (IFN- $\alpha$ ), in part through viral nucleic acid interactions with distinct pathogen-associated molecular pattern recognition receptors, such as Toll-like receptors on cell surface and/or intracellular sensors, such as retinoic acid-inducible gene I like helicases in the infected host cells. ${ }^{8-11}$ The IFN signaling pathways activate IFN-stimulated genes (ISGs), which play critical roles in the host innate defense against HCV infection through repressing viral replication and enhancing cellular immune responses.9,11,12 Pegylated IFN $-\alpha$ plus ribavirin therapy became the standard therapy for HCV viral infection recently. However, the therapy failed to cure all patients who underwent the treatment. In addition, patients may encounter specific adverse effects that require therapy withdrawal. ${ }^{13}$ The interplay of the virus, environmental factors and the host immunity is implicated as the key process for the natural heterogeneity of viral clearance and liver injury. ${ }^{14-19}$ It remains a critical issue with regard to the viral persistence and the response to anti-viral therapy in individual patient.

Interferon $\lambda($ IFN $-\lambda)$ is classified as the type 3 IFN that includes three subtypes (IFN- $\lambda 1,2$ and 3 ). IFN- $\lambda$ s have pleiotropic cellular functions. The ligand receptor 
interaction triggers signaling pathways similar to those by IFN- $\alpha$ and $\beta .^{20,21}$ IFN- $\lambda$ s are produced and expressed in antigen-presenting cells. IFN- $\lambda s$ have lower antiviral activities than IFN- $\alpha$. However, IFN- $\lambda$ s have critical roles in fighting against viral infection. ${ }^{22-24}$ Recently, four genome-wide association studies concurrently provided the overwhelming evidence that single-nucleotide polymorphisms (SNPs) of IFN- $\lambda 3$ (also known as IL28B) on chromosome $19 \mathrm{q} 13$ contribute to IFN treatment response and spontaneous HCV clearance in HCV infection. ${ }^{25-29}$ Meanwhile, IL28B genetic variations influence the IL28B mRNA expressions, which may have a role in the regulation of intra-hepatic ISG expression. ${ }^{26,27}$ IL28B SNPs seem to impact the treatment response to pegylated IFN- $\alpha$ /ribavirin for chronic $\mathrm{HCV}$ infection among several ethnic populations. ${ }^{25-29}$ In this study, we investigated whether the IL28B polymorphisms are associated with susceptibility to HCV infection and with response to the therapy of IFN and ribavirin in Taiwanese chronic $\mathrm{HCV}$ infection patients.

\section{Results}

Clinical characteristics of chronic HCV infection patients This study recruited 728 Taiwanese patients with chronic $\mathrm{HCV}$ infection including 444 men and 284 women who received IFN- $\alpha$ plus ribavirin therapy. The mean ages on therapy were $51.2 \pm 10.4$ (ranged 19.2-76.5) years old. Among them, 126 patients (112 patients were treated for a period of 24 weeks and 14 patients for 48 weeks) received treatment of INTRON 5MU three times a week in combination of $1200 \mathrm{mg}$ ribavirin daily. The remaining 602 patients received ribavirin $(1200 \mathrm{mg})$ daily and pegylated IFN- $\alpha$ every week (499 patients were treated for a period of 24 weeks and 103 patients for 48 weeks). Of the total 728 chronic HCV patients, 559 (76.8\%) revealed sustained virological response (SVR) to IFN (INTRON or pegylated IFN- $\alpha$ ) plus ribavirin therapy. In addition, $424(58.2 \%)$ were identified as HCV genotype 1 viral infection and $318(43.7 \%)$ were detected with viral load over $400000 \mathrm{IU} \mathrm{ml}^{-1}$ (Table 1). The liver biopsies showed that $246(33.8 \%)$ were in cirrhosis stage, 114
(15.7\%) in severe fibrosis stage and 368 (50.5\%) in mild

\section{Clinical characteristics affect SVR during the treatment of chronic HCV infection}

We examined the possible factors that may contribute to the SVR of chronic HCV infection. As shown in Table 2, age at therapy and gender were important host factors that affected the SVR. Patients with younger age at therapy were more likely to have higher SVR rate in chronic HCV infection (adjusted $P=0.0004$, odds ratio (OR) $0.962 ; 95 \%$ confidence interval (CI): 0.942-0.983). The SVR rate tended to be higher $(81.3 \%)$ in men than in women $(69.8 \%$ ) (adjusted $P=0.0093$, OR $1.705 ; 95 \% \mathrm{CI}$ : 1.140-2.549). Non-cirrhosis (mild and severe fibrosis) is another critical factor that demonstrated high SVR in comparison with cirrhosis (adjusted $P=4.1 \times 10^{-6}$, OR 0.379; 95\% CI: 0.251-0.573). Body mass index below $27 \mathrm{~kg} \mathrm{~m}^{-2}$ showed modest effect on the higher SVR (adjusted $P=0.0486$, OR 0.616; 95\% CI: 0.381-0.997). There was no significant SVR difference between the patients with INTRON plus ribavirin (76.6\%) and those with pegylated IFN- $\alpha$ plus ribavirin $(77.8 \%)$ albeit the percentage of patients with high viral RNA were lower in INTRON plus ribavirin group $(19.0 \%)$ than that in pegylated IFN- $\alpha$ plus ribavirin $(48.8 \%)$ group. Viral genotypes were significantly associated with SVR. Patients with non-HCV genotype 1 infection (91.4\%; 278 of 304 ) were more likely to reveal SVR than the patients with HCV genotype 1 infection $(66.3 \%$ ) (adjusted $P=3.6 \times 10^{-12}$, OR 0.178; 95\% CI: $\left.0.110-0.290\right)$. In addition, $86.6 \%$ of the patients with viral load $<400000 \mathrm{IU} \mathrm{m}^{-1}$ demonstrated SVR as compared with $64.2 \%$ of the patients with $\mathrm{HCV}$ viral load over $400000 \mathrm{IU} \mathrm{ml}^{-1}$ (adjusted $P=2.3 \times 10^{-9}$, OR 0.292; 95\% CI: 0.195-0.437). Therefore, viral load appeared to contribute significantly to the SVR in the therapy.

\section{IL28B polymorphisms are associated with chronic $\mathrm{HCV}$ infection}

Ten SNPs of IL28B genetic variations were genotyped in 728 chronic HCV infection patients and 960 healthy

Table 1 Clinical characteristics and SVR analysis of Taiwanese patients with chronic HCV infection

\begin{tabular}{lccc}
\hline Clinical characteristic & Total $(\mathrm{N}=728)$ & SVR positive $(\mathrm{N}=559)$ & SVR negative $(\mathrm{N}=169)$ \\
\hline Age on IFN therapy & $51.2 \pm 10.4$ & $50.1 \pm 10.5$ & $54.8 \pm 9.3$ \\
$\quad$ Male & $444(61.0 \%)$ & $361(64.6 \%)$ & $83(49.1 \%)$ \\
Liver cirrhosis & $246(33.8 \%)$ & $155(27.7 \%)$ & $91(53.8 \%)$ \\
HCV genotype: & & & $<0.001^{*}$ \\
Genotype 1 & $424(58.2 \%)$ & $281(50.3 \%)$ & $143(84.6 \%)$ \\
Non-genotype 1 & $304(41.8 \%)$ & $278(49.7 \%)$ & $26(15.4 \%)$ \\
HCV RNA $\geq 0.4$ miu & $318(43.7 \%)$ & $204(36.5 \%)$ & $114(67.5 \%)$ \\
BMI $\geq 27$ kg m ${ }^{-2}$ & $146(20.1 \%)$ & $106(19.0 \%)$ & $40(23.7 \%)$ \\
Adherence & $483(66.3 \%)$ & $386(69.1 \%)$ & $39(23.1 \%)$ \\
Regimen & & & $<0.001^{*}$ \\
INTRON+RBV & $126(17.3 \%)$ & $98(17.5 \%)$ & $28(16.6 \%)$ \\
PEG-IFN+RBV & $602(82.7 \%)$ & $461(82.5 \%)$ & $141(83.4 \%)$ \\
\hline
\end{tabular}

Abbreviations: BMI, body mass index; HCV, hepatitis C virus; PEG IFN, pegylated interferon; RBV, ribavirin; SVR, sustained virological response.

$* P<0.05$. 
Table 2 Clinical characteristics significantly affect SVR by multiple varieties analysis in 728 Taiwanese chronic HCV infection patients

\begin{tabular}{|c|c|c|c|c|}
\hline \multirow[t]{2}{*}{ Clinical characteristics } & \multirow[t]{2}{*}{$\mathrm{N}$} & \multicolumn{3}{|c|}{ Stepwise logistic regression } \\
\hline & & OR & $95 \% C I$ & P-value \\
\hline Age on IFN therapy & 728 & 0.962 & $0.942-0.983$ & 0.0004 \\
\hline Gender: female & 284 & 1.705 & $1.140-2.549$ & 0.0093 \\
\hline BMI: below $27 \mathrm{~kg} \mathrm{~m}^{-2}$ & 582 & 0.616 & $0.381-0.997$ & 0.0486 \\
\hline HCV RNA viral load $\leq 400000 \mathrm{IU} \mathrm{ml}^{-1}$ & 410 & 0.292 & $0.195-0.437$ & $2.3 \times 10^{-9}$ \\
\hline HCV genotype: Non-genotype 1 & 304 & 0.178 & $0.110-0.290$ & $3.6 \times 10^{-12}$ \\
\hline Liver biopsy: non-cirrhosis & 482 & 0.379 & $0.251-0.573$ & $4.1 \times 10^{-6}$ \\
\hline
\end{tabular}

Abbreviations: BMI, body mass index; $\mathrm{CI}$, confidence interval; $\mathrm{HCV}$, hepatitis $\mathrm{C}$ virus; OR, odds ratio; SVR, sustained virological response.

Table 3 Allele and genotype distributions of IL28B SNPs in 728 Taiwanese chronic HCV infection patients and 960 normal controls

\begin{tabular}{|c|c|c|c|c|c|c|c|}
\hline \multirow[t]{2}{*}{ SNP marker } & \multirow[t]{2}{*}{ Risk allele } & \multirow[t]{2}{*}{ RAF (normal) } & \multirow[t]{2}{*}{$R A F(H C V)$} & \multirow[t]{2}{*}{$\mathrm{P}_{\text {trend }}$} & \multirow[t]{2}{*}{ Genotypes/alleles } & \multicolumn{2}{|c|}{ Age, sex adjusted } \\
\hline & & & & & & P-value & OR $(95 \% C I)$ \\
\hline rs28416813 & $\mathrm{C}$ & 0.975 & 0.999 & $1.0 \times 10^{-6}$ & $\begin{array}{c}\mathrm{C} / \mathrm{G}+\mathrm{G} / \mathrm{G} \text { vs } \mathrm{C} / \mathrm{C} \\
\mathrm{G} \text { vs } \mathrm{C}\end{array}$ & $\begin{array}{l}1.5 \times 10^{-5} \\
6.4 \times 10^{-7}\end{array}$ & $\begin{array}{l}0.012(0.002-0.089 \\
0.026(0.006-0.110)\end{array}$ \\
\hline rs8099917 & $\mathrm{T}$ & 0.936 & 0.947 & 0.2006 & $\begin{array}{c}\mathrm{G} / \mathrm{G} \text { vs } \mathrm{G} / \mathrm{T}+\mathrm{T} / \mathrm{T} \\
\mathrm{G} \text { vs } \mathrm{T}\end{array}$ & $\begin{array}{l}0.0010 \\
0.0425\end{array}$ & $\begin{array}{l}0.034(0.004-0.254 \\
0.713(0.515-0.989\end{array}$ \\
\hline
\end{tabular}

Abbreviations: $\mathrm{CI}$, confidence interval; $\mathrm{HCV}$, hepatitis $\mathrm{C}$ virus; OR, odds ratio; RAF (normal) and RAF (HCV), risk allele frequency in normal controls and HCV patients; SNP, single-nucleotide polymorphism.

$P_{\text {trend }}$ value were calculated by the Cochran-Armitage trend test with permutation $=100000$.

controls. As shown in Table 3, genotype distributions and allele frequencies of two IL28B SNPs were significantly different between patients with chronic $\mathrm{HCV}$ infection and the normal healthy donors. The $\mathrm{C}$ allele of SNP rs28416813 appeared to be a risk allele for HCV infection (Trend test $P=1.0 \times 10^{-6}$ with 100000 permutations; $G$ vs $C$ adjusted $P=6.4 \times 10^{-7}$, OR $0.026,95 \% \mathrm{CI}$ : 0.006-0.110; genotypes CG + GG vs CC adjusted $P=1.5 \times 10^{-5}$, OR 0.012, 95\% CI: 0.002-0.089). In addition, the SNP rs8099917 genotypes appear to be a predisposition factor for $\mathrm{HCV}$ infection (genotype GG vs GT + TT adjusted $P=0.001$, OR $0.034 ; 95 \%$ CI: $0.004-$ 0.254). Therefore, the SNP rs8099917 GG could be defined as the protective genotype. Notably, the SNP rs8099917 GG genotype frequency of the normal control males tested negative for HCV antibody was 21.5 times of that in the male patients with HCV infection (Table 4). Significant deviations from Hardy-Weinberg equilibrium in genotype and allele distributions were observed for SNP rs28416813 and rs8099917 in both HCV patients and normal controls $(P<0.05)$.

IL28B polymorphisms are associated with SVR in the treatment of chronic HCV infection

Patients with chronic HCV infection may manifest heterogeneous clinical characteristics and exhibit different SVRs to IFN therapy. Hence, we stratified patients into two groups in accordance with SVR to the treatment. As shown in Table 3, genotype distributions of the eight SNPs (rs12980275, rs8105790, rs11881222, rs4803219, rs12979860, rs8099917, rs7248668 and rs10853728) were significantly different between SVR positive and negative patients (Trend test $P=0.005$ with 100000 permutations). The advantageous alleles of IL28 polymorphisms had similarly high frequencies in SVR positive groups
(Table 5). Consequently, we examined whether IL28B SNP haplotypes were associated with SVR based on linkage disequilibrium blocks (Figure 1). As shown in Table 6, IL28B haplotypes ACC (rs11881222, rs4803219 and rs12979860), AT (rs12980275 and rs8105790), ATA (rs12980275, rs8105790 and rs11881222) and TA (rs8105790 and rs11881222) revealed as low responder alleles. Our data suggest that genetics of IL28B may impact the SVR in the treatment of $\mathrm{HCV}$ infection in Taiwanese.

\section{IL28B polymorphisms are associated with HCV genotypes} of chronic HCV infection

We also investigated possible interactions of IL28B polymorphisms with other clinical characteristics of chronic HCV infection in Taiwanese. We observed significant association $(P<0.05)$ between $\mathrm{HCV}$ genotypes and IL28B SNP rs8099917 (Trend test $P=0.03$ with 100000 permutations; $G$ vs $\mathrm{T}$ adjusted $P=0.0318$, OR 1.729, 95\% CI: 1.049-2.851) and between HCV genotypes and rs7248668 (Trend test $P=0.028$ with 100000 permutations; A vs $G$ adjusted $P=0.0267, \mathrm{OR} 1.777,95 \% \mathrm{CI}$ : 1.069-2.956). Our data suggest that IL28B gene products may associate with certain strains of $\mathrm{HCV}$ infection. Next, we performed multivariate analysis to comparatively evaluate the independent contribution of the significant IL-28B SNPs and the non-genetic clinical characteristics. Notably, rs12979860 is the only IL28B SNP showed significant association in multivariate analysis $\left(P=2.3 \times 10^{-8}\right.$, OR $0.177,95 \%$ CI: $\left.0.096-0.324\right)$.

\section{Discussion}

Chronic HCV infection involves in a complex interaction of virus with host innate and adaptive immunity. 


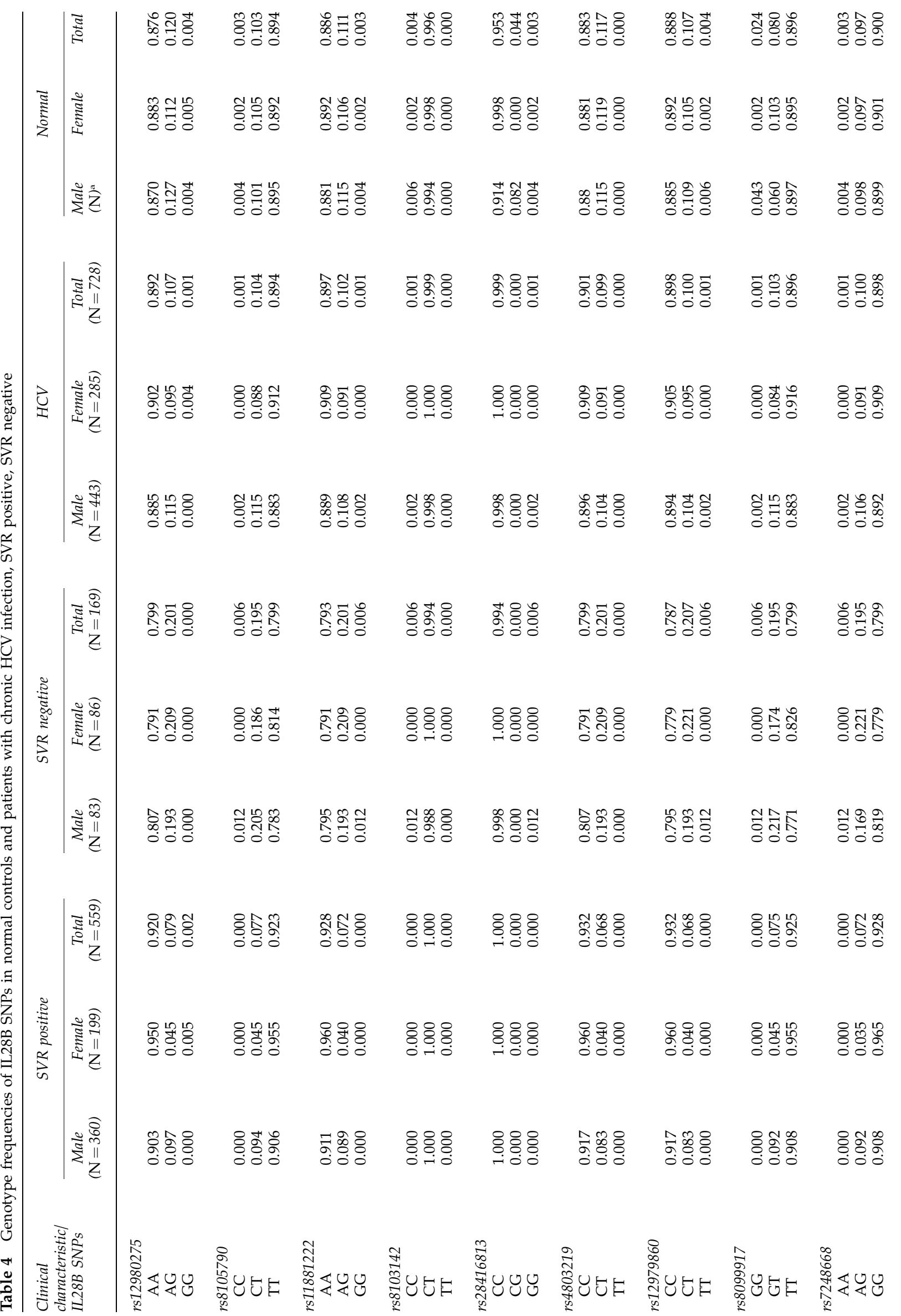


Although the acute infections are highly amenable to therapy, approximately $80 \% \mathrm{HCV}$ infections progress to viral persistence. ${ }^{2,5}$ Several host factors including alcohol intake, age at the time of infection, gender and coinfection with the hepatitis B virus or human immunodeficiency virus are known to affect disease courses in $\mathrm{HCV}$ infection. ${ }^{1,5,13,14}$ Accumulating evidence supports a critical role of host genetics in immune responses, which may predict the treatment response and outcome of viral clearance. ${ }^{18,30,31}$ Consistent with previous reports, this study established a predictive role of IL28B polymorphisms in the treatment of chronic $\mathrm{HCV}$ infection with IFN- $\alpha$ plus ribavirin in Taiwanese patients.

HCV evades the host immune surveillance by triggering production of viral inhibitory enzymes and negative signal regulatory proteins that block signal transduction pathways of human innate immune system. ${ }^{19,32}$ In addition, HCV employs multiple escaping strategies including viral genetic variability (genotype switches), baseline viral load, quasi-species entity and high viral turnover to protect HCV from host humoral and cellular immunity. ${ }^{16,19,32,33}$ Our data provided direct evidence that HCV genotype 1 and high basal viral load are two key factors for SVR in the treatment of Taiwanese HCV patients.

IFN- $\lambda 1$ (IL29), IFN- $\lambda 2$ (IL28A) and IFN- $\lambda 3$ (IL28B) belong to type II cytokine family induced by virus infections. Besides their antivirus activities, IFN- $\lambda s$ are capable of modulating innate immune response effects. ${ }^{21}$ IFN- $\lambda s$ bind to the heterodimeric receptors of specific IFN- $\lambda$ R1 and common IL10R2, which form a trimeric ISG factor complex that triggers a cascade of signal transductions. $^{34}$ The binding of ISG factor to IFN response elements results in steady upregulations of several ISGs with antiviral effects. ${ }^{35-38}$ In animal models, the antiviral activity of Toll-like receptor signaling pathways induced by Toll-like receptor-3 and 9 agonists was significantly decreased in IL28R1 knockout mice. ${ }^{39}$ In gene expression comparison studies, peripheral blood and liver tissue cells in chronic HCV infection with low SVR in response to IFN/ribavirin therapy display a defect in ISG production, which may be due to pre-activated states in blunted IFN cell signaling. ${ }^{40-42}$ These findings point to the critical roles of host genetic variations in IFN- $\alpha-$ mediated innate immune signal pathways that may affect chronic $\mathrm{HCV}$ infection course and treatment response. Indeed, certain host genetic polymorphisms involving in IFN signal pathways and ISGs have shown modest effects on IFN- $\alpha$ treatment response in patients infected with $\mathrm{HCV}^{43-45}$

$\mathrm{HCV}$ persistent infection induces a cascade of innate and adaptive immune cellular dysfunctional changes. ${ }^{4,17}$ IFN- $\lambda$ s produced by monocyte-derived dendritic cells and plasmacytoid dendritic cells facilitate viral clearance by influencing innate and adaptive immunities. ${ }^{22,46,47}$ IL2 9 and IFN- $\alpha$ modulate the co-stimulatory molecules expressions on plasmacytoid dendritic cells and lead to signature cytokines production. ${ }^{48}$ In addition, IL29 modulates the Th1/Th2 differentiation that favors the pro-inflammatory (Th1) response, which enhance adaptive cellular immunity to eradicate virus infection. ${ }^{49-52}$ During vaccination, IL28B increases the cytolytic CD8T cell differentiations and suppresses the of $\mathrm{T}$ regulatory cell productions, which protect animals from mortality after a lethal influenza challenge. ${ }^{52}$ These immunological 
Table 5 Association of IL28B SNPs with SVR in Taiwanese patients with chronic HCV infection

\begin{tabular}{|c|c|c|c|c|c|c|c|c|c|}
\hline \multirow{2}{*}{$\begin{array}{l}\text { SNP } \\
\text { marker }\end{array}$} & \multirow{2}{*}{$\begin{array}{l}\text { Risk } \\
\text { allele }\end{array}$} & \multirow{2}{*}{$\begin{array}{l}R A F \\
(N R)\end{array}$} & \multirow{2}{*}{$\begin{array}{c}R A F \\
(S V R)\end{array}$} & \multirow[t]{2}{*}{$\mathrm{P}_{\text {trend }}$} & \multirow[t]{2}{*}{ Genotypes/alleles } & \multicolumn{2}{|c|}{ Age, sex adjusted } & \multicolumn{2}{|c|}{ Stepwise logistic regression } \\
\hline & & & & & & P-value & OR $(95 \% C I)$ & P-value & OR $(95 \% C I)$ \\
\hline \multirow[t]{2}{*}{ rs4803219 } & $\mathrm{C}$ & 0.899 & 0.966 & $2.0 \times 10^{-6}$ & $\mathrm{C} / \mathrm{T}$ vs $\mathrm{C} / \mathrm{C}$ & $3.7 \times 10^{-7}$ & $0.258(0.153-0.435)$ & $1.4 \times 10^{-7}$ & $0.191(0.103-0.354)$ \\
\hline & & & & & T vs $C$ & $7.4 \times 10^{-7}$ & $0.284(0.172-0.467)$ & $2.1 \times 10^{-7}$ & $0.213(0.119-0.382)$ \\
\hline \multirow{2}{*}{ rs12979860 } & $\mathrm{C}$ & 0.891 & 0.966 & $1.0 \times 10^{-6}$ & $\mathrm{C} / \mathrm{T}+\mathrm{T} / \mathrm{T}$ vs $\mathrm{C} / \mathrm{C}$ & $4.4 \times 10^{-8}$ & $0.236(0.140-0.395)$ & $3.1 \times 10^{-8}$ & $0.181(0.099-0.331)$ \\
\hline & & & & & T vs $C$ & $3.5 \times 10^{-8}$ & $0.252(0.155-0.411)$ & $2.9 \times 10^{-8}$ & $0.200(0.113-0.353)$ \\
\hline \multirow[t]{2}{*}{ rs11881222 } & A & 0.894 & 0.964 & $1.0 \times 10^{-6}$ & $\mathrm{~A} / \mathrm{G}+\mathrm{G} / \mathrm{G}$ vs $\mathrm{A} / \mathrm{A}$ & $2.1 \times 10^{-7}$ & $0.256(0.153-0.428)$ & $1.1 \times 10^{-7}$ & $0.195(0.107-0.356)$ \\
\hline & & & & & G vs A & $1.6 \times 10^{-7}$ & $0.272(0.167-0.443)$ & $9.0 \times 10^{-8}$ & $0.214(0.121-0.376)$ \\
\hline \multirow[t]{2}{*}{ rs12980275 } & A & 0.899 & 0.959 & $4.9 \times 10^{-5}$ & $A / G+G / G$ vs $A / A$ & $3.4 \times 10^{-6}$ & $0.302(0.182-0.500)$ & $2.0 \times 10^{-6}$ & $0.241(0.134-0.433)$ \\
\hline & & & & & G vs A & $1.0 \times 10^{-5}$ & $0.340(0.211-0.549)$ & $4.3 \times 10^{-6}$ & $0.275(0.158-0.476)$ \\
\hline \multirow[t]{2}{*}{ rs8105790 } & $\mathrm{T}$ & 0.896 & 0.962 & $9.0 \times 10^{-6}$ & $\mathrm{C} / \mathrm{C}+\mathrm{C} / \mathrm{T}$ vs $\mathrm{T} / \mathrm{T}$ & $1.3 \times 10^{-6}$ & $0.282(0.169-0.471)$ & $5.5 \times 10^{-7}$ & $0.222(0.123-0.400)$ \\
\hline & & & & & C vs $\mathrm{T}$ & $9.5 \times 10^{-7}$ & $0.298(0.184-0.484)$ & $7.5 \times 10^{-7}$ & $0.248(0.143-0.431)$ \\
\hline \multirow[t]{2}{*}{ rs8099917 } & $\mathrm{T}$ & 0.896 & 0.962 & $5.0 \times 10^{-6}$ & $\mathrm{G} / \mathrm{G}+\mathrm{G} / \mathrm{T}$ vs $\mathrm{T} / \mathrm{T}$ & $9.6 \times 10^{-7}$ & $0.277(0.165-0.462)$ & $4.3 \times 10^{-7}$ & $0.217(0.120-0.392)$ \\
\hline & & & & & G vs T & $7.1 \times 10^{-7}$ & $0.293(0.180-0.476)$ & $6.2 \times 10^{-7}$ & $0.245(0.141-0.426)$ \\
\hline \multirow[t]{2}{*}{ rs7248668 } & G & 0.896 & 0.964 & $4.0 \times 10^{-6}$ & $\mathrm{~A} / \mathrm{A}+\mathrm{A} / \mathrm{G}$ vs $\mathrm{G} / \mathrm{G}$ & $6.1 \times 10^{-7}$ & $0.268(0.160-0.450)$ & $3.6 \times 10^{-6}$ & $0.246(0.136-0.445)$ \\
\hline & & & & & A vs $G$ & $4.5 \times 10^{-7}$ & $0.283(0.173-0.462)$ & $4.5 \times 10^{-6}$ & $0.270(0.154-0.472)$ \\
\hline \multirow[t]{3}{*}{ rs10853728 } & $\mathrm{C}$ & 0.746 & 0.924 & 0.0015 & $\mathrm{G} / \mathrm{G}+\mathrm{C} / \mathrm{G}$ vs $\mathrm{C} / \mathrm{C}$ & 0.0007 & $0.533(0.371-0.767)$ & 0.0006 & $0.485(0.322-0.731)$ \\
\hline & & & & & $\mathrm{G} / \mathrm{G}$ vs $\mathrm{C} / \mathrm{G}+\mathrm{C} / \mathrm{C}$ & 0.0109 & $0.330(0.141-0.775)$ & 0.0117 & $0.291(0.111-0.759)$ \\
\hline & & & & & G vs C & 0.0002 & $0.564(0.418-0.761)$ & 0.0002 & $0.527(0.375-0.740)$ \\
\hline
\end{tabular}

Abbreviations: CI, confidence interval; $\mathrm{HCV}$, hepatitis $\mathrm{C}$ virus; NR, no response; OR, odds ratio; RAF, risk allele frequency; SNP, singlenucleotide polymorphism; SVR, sustained virological response.

Risk allele, the allele with higher frequency in cases compared with controls.

$P_{\text {trend }}$ value was calculated by the Cochran-Armitage trend test with 100000 permutations.

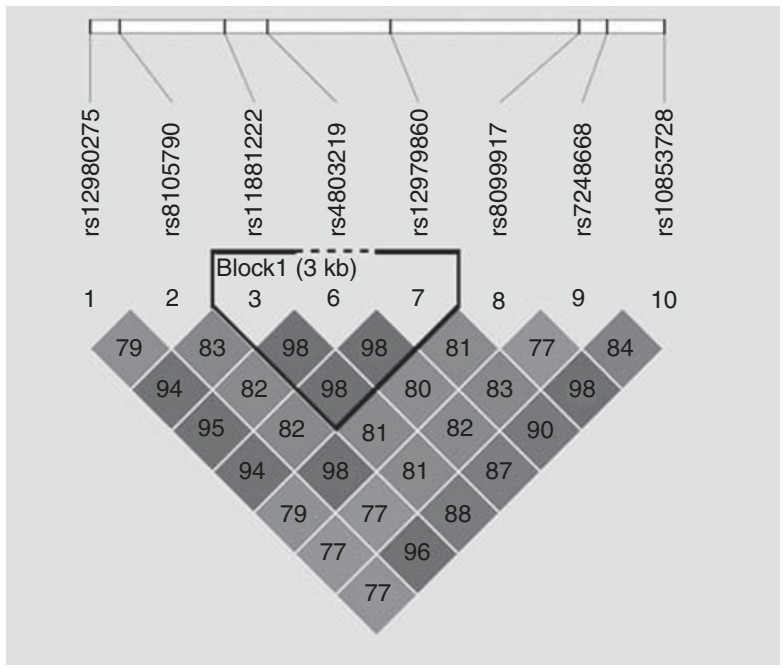

Figure 1 Pairwise linkage disequilibrium (LD) patterns for eight polymorphisms through IL28B regions.

responses collectively suggest IFN- $\lambda \mathrm{s}$ are critical in suppressing viral replication during $\mathrm{HCV}$ chronic infection. However, the mechanisms that IL28B SNPs are associated with the response to IFN- $\alpha$-based therapy remain to be elucidated in humans.

In therapy with pegylated IFN- $\alpha$ plus ribavirin, the adverse events and failure of response sometimes occurred. ${ }^{13}$ The novel HCV treatment strategies are still under development to improve sustained response rates. IFN- $\lambda$ s have several important roles in controlling chronic HCV infections and may be useful in future therapy. IFN- $\lambda$ s can enhance the subsaturating levels of IFN- $\alpha$ and increase the antiviral efficacy. ${ }^{35}$ The combination of IFN- $\lambda$ s and IFN- $\alpha$ s may provide the additive therapy effect through the complementary roles of two types of cytokines. ${ }^{37,38,53}$ As the distribution of IFN- $\lambda$ receptors are restricted on plasmacytoid dendritic cells, peripheral B cell, hepatocytes and epithelial cells, IFN- $\lambda \mathrm{s}$ may be used to target specific cell responses and to avoid the adverse events of therapy of IFN- $\alpha$ s. $^{53,54}$

Genome-wide association studies in independent populations confirmed that IL28B genetic variations are associated with HCV IFN-based therapy response and spontaneous clearance of HCV. ${ }^{25-29}$ In this study, we compared genotypes and alleles frequency of IL28B SNPs between normal controls and patients with chronic HCV infection in Taiwanese. In Caucasians and Africans, IL28B SNP rs12979860 CC genotype and C allele are associated with spontaneous resolution of $\mathrm{HCV}$ infection, however, no differences in genotype and allele distributions were observed for IL28B SNP rs12979860 between $\mathrm{HCV}$ patients and normal controls in Taiwanese. Paradoxically, rs8099917 GG genotype and rs28416813 G allele that associated with low response in Australians and Japanese were significantly enriched in Taiwanese normal male population. On the other hand, eight SNPs with strong linkage disequilibrium demonstrate significant associations with SVR on single point analysis. However, haplotype analysis failed to increase the significance of association, which is different from the results of previous studies. ${ }^{26,27}$ These findings suggest that various IL28B SNPs are associated with the treatment response of HCV in Taiwanese. Nevertheless, the exact causal roles of IL28B polymorphisms remain to be elucidated.

The combinational treatment of pegylated IFN $-\alpha$ and ribavirin is widely applied to chronic HCV infection. The treatment results in sustained clearance of virus and clinical improvement in various ethnic populations. ${ }^{13,55-58}$ However, the response rates showed ethnic difference with poor response in patients of African 
ancestry and Hispanic ancestry in comparison with patients of Caucasian ancestry. ${ }^{55,56}$ We observed higher SVR rates in Taiwanese chronic HCV infection who received IFN- $\alpha$ and ribavirin combination therapy, similar to the previous findings in Asians. ${ }^{57,58}$ The IL28B genetic variations affect mRNA expressions, indicating functional polymorphisms in regulatory regions may interfere with treatment responses. ${ }^{26,27}$ This study confirmed that IL28B SNPs are associated with SVR of HCV treatment response across all ethnic groups. The advantageous IL28B SNPs have significantly higher frequencies in Asian populations than in populations with African and Caucasian ancestry origins, which may provide explanation for the ethnic differences in SVR in IFN-based therapy among Asians, Europeans and Africans.

Recognizing the cost-effective concern and the potentially serious adverse effects, investigators and clinicians put emphasis on the importance of predicting the response to IFN-based biologic therapy. The longer duration of treatment achieved significantly higher SVR rates than the shorter course therapy, which may indicate the specific refractory cases with genotype 1 infection. ${ }^{58,59}$ Human genome variations explain part of the different effective responses. The combination of data including virus genotypes, viral load, immunological cellular and gene expression changes, and host genetic variations may be critical to determine individual appropriate treatment doses and duration, which is valuable to minimize the adverse effects of biologic agents. This study could provide another critical evidence for usefulness of application of genetic data in clinical settings for predicting the treatment response. In Asians, patients carrying IL28B low response alleles and genotypes could be identified for longer antiviral treatment. However, SVR of HCV infection is determined by multiple genetic loci. The practical utility of genetic data in treatment choice remains to be determined for IFN-based therapy.

In conclusion, IFN- $\lambda$ s appear as critical functional immune response molecules that could be therapeutic target in the treatment of persistent $\mathrm{HCV}$ infections. Genetic data of IL28B SNPs may provide novel guidelines in determining optimal treatment duration with IFN-based therapies.

\section{Materials and methods}

Study subjects

This study recruited 728 patients from the Hepatology clinics of Linkou Medical Center, Chang Gung Memorial Hospital. Hepatology specialists confirmed the chronic $\mathrm{HCV}$ infection clinically and verified the diagnosis with liver biopsies in all examined patients. Two cohorts of patients with chronic hepatitis $\mathrm{C}$ were analyzed. Patients in cohort $\mathrm{A}$ were treated with INTRON plus ribavirin (126 patients, January 1988 to October 2001) and patients in cohort B were treated with pegylated IFN plus ribavirin (604 patients, November 2001 to December 2008). All patients were positive for anti-HCV (for $>6$ months) and for HCV-RNA. In addition, HCV from each patient was genotyped and the infections were verified with pathological findings before the enrolment for treatment. The patients in cohort $A$ received INTRON 
(IFN- $\alpha$ 2b, Schering Co., Kenilworth, NJ, USA) 5 MU three times a week and ribavirin $1200 \mathrm{mg}$ per day. The cohort B patients received ribavirin $1200 \mathrm{mg}$ per day and PEGINTRON $\left(15 \mu \mathrm{g} \mathrm{kg}^{-1}\right.$ week $^{-1}$, Peginterferon- $\alpha 2 \mathrm{~b}$, Schering Co.) or PEGASYS (180 $\mu \mathrm{g}_{\text {week }^{-1}}$, Peginterferon$\alpha 2 \mathrm{a}$, Roche). For the purpose of this study, a total of 960 healthy blood donors (514 men and 446 women) were recruited following a questionnaire survey to exclude any donors with autoimmune diseases including rheumatoid arthritis, systemic lupus erythematous, ankylosing spondylitis, and autoimmune thyroiditis, diabetes mellitus, viral hepatitis (HBV and HCV) infections and cardiovascular diseases. The age of healthy control donors ranges from 18 to 64 years old with a mean age of $40.3 \pm 10.7$.

\section{HCV infection assays}

Clinical characteristics including liver biochemical test, $\mathrm{HCV}$ genotypes, HCV viral load, liver histology and therapeutic responses to the combination regimen (IFN- $\alpha$ plus ribavirin). The HCV antibody was tested by the Abbott AxSYM anti-HCV 3.0 (Abbott Laboratories, Abbott Park, IL, USA). The HCV RNA detection was carried out with Cobas Amplicor HCV v2.0 kit (Roche Diagnostics Co., Indianapolis, IN, USA; lower limit of detection of at concentrations of $50 \mathrm{IU} \mathrm{ml}^{-1}$ ) and RNA was quantitated by the VERSANT HCV RNA 3.0 Assay (bDNA) (Bayer Diagnostics, Berkeley, CA, USA; lower limit of detection of at $615 \mathrm{IU} \mathrm{ml}^{-1}$ ) or COBAS TaqMan HCV Test (TaqMan HCV; Roche Molecular Systems Inc., Branchburg, NJ, USA; lower limit of detection of at concentrations of $15 \mathrm{IU} \mathrm{ml}^{-1}$ ). The baseline levels of HCV-RNA were determined by VERSANT HCV RNA 3.0 Assay in 669 patients and confirmed by Cobas Amplicor HCV v2.0 before January, 2008. Thereafter, COBAS TaqMan HCV Test was applied in 59 patients. HCV RNA level <2 MEQ (equal to $400000 \mathrm{IU} \mathrm{m}^{-1}$ ) was defined as low viral load. HCV genotypes were analyzed using a genotype-specific probe-based assay in the 50 untranslated region.

\section{Clinical SVR and liver biopsy}

SVR was defined when serum HCV-RNA was undetectable at the end of therapy and at 24-week follow-up after the treatment. Non-response was designated when viral RNA reappears within 6 months after the cessation of treatment; or when viral load decreases $<2$ logs after $12-$ week treatment, or when viral RNA was detectable at the end of treatment. The liver biopsy was interpreted and graded by Ishak classification. In the analysis, we categorized fibrosis into cirrhosis (fibrosis score 5 or 6), severe fibrosis (fibrosis score 4 ) and mild fibrosis (fibrosis score 1 or 2 or 3 ).

\section{Nucleic acid isolation}

Anti-coagulated peripheral blood was obtained from healthy normal blood donors and HCV patients. Genomic DNA was isolated from EDTA anti-coagulated peripheral blood using the Puregene DNA isolation kit (Gentra Systems, Minneapolis, MN, USA) as previously described. ${ }^{60}$

Taqman-based assay for the genotyping of SNPS

The oligonucleotide sequences flanking IL28B polymorphisms were designed as primers for Taqman allelic discrimination assays. Allele-specific primers were labeled with a fluorescent dye (FAM or VIC) and used in the PCR reaction. Aliquots of the PCR products were genotyping using allele specific probe of SNPs on a realtime PCR Thermocylcler (ABI, Foster City, CA, USA).

\section{Statistical analysis}

We carried out single-locus analyses of IL28B polymorphisms for 960 normal healthy controls and 728 patients with chronic HCV infection. Three $\chi^{2}$ tests: the genotype test, the allele test and Cochran-Armitage trend test were performed, and associations with SNPs $(P<0.05)$ were identified using the SAS/Genetics software package release 8.2 (SAS Institute, Cary, NC, USA). For the analysis of risk genotypes/alleles, we used logistic regression models adjusted for age and sex and calculated $P$-values, ORs, and their 95\% CIs. Linkage disequilibrium between marker loci was assessed and haplotype blocks were constructed using Haploview 4.1 (Broad Institute of MIT and Harvard; http://www. broad.mit.edu/mpg/haploview). For the markers within the same haplotype block, we used disease status (case vs control) and five clinical characteristics: body mass index, drug, HCV genotype, HCV RNA viral load and SVR as traits and tested for the haplotype-trait association utilizing SAS HAPLOTYPE procedure. To investigate the genetic association with clinical characteristics including body mass index, drug, $\mathrm{HCV}$ genotype, $\mathrm{HCV}$ RNA viral load and SVR for the case group, we controlled for each of these five characteristics and performed stepwise logistic regression analyses. Additionally, we examined the association of SVR with age on IFN therapy, gender, body mass index, HCV RNA viral load, HCV genotype, adherence and degrees of liver fibrosis in the chronic HCV infection patients using Student's $t$-test and $\chi^{2}$ test. The $5 \%$ level of significance for $P$-values was used for all the analyses.

\section{Conflict of interest}

The authors declare no conflict interest.

\section{Acknowledgements}

We thank Shin Chu Blood Donor Center for samples collection. This study was supported by grants from the Chang Gung Memorial Hospital (No. CMRPG 380681 and CMRPG 360113).

\section{References}

1 Shepard CW, Finelli L, Alter M. Global epidemiology of hepatitis C virus infection. Lancet Infect Dis 2005; 5: 558-567.

2 Villano SA, Vlahov D, Nelson KE, Cohn S, Thomas DL. Persistence of viremia and the importance of long-term follow-up after acute hepatitis C infection. Hepatology 1999; 29: 908-914.

3 Thimme R, Oldach D, Chang KM, Steiger C, Ray SC, Chisari FV. Determinants of viral clearance and persistence during acute hepatitis C virus infection. J Exp Med 2001; 194: 1395-1406.

4 Pachiadakis I, Pollara G, Chain BM, Naoumov NV. Is hepatitis $C$ virus infection of dendritic cells a mechanism facilitating viral persistence? Lancet Infect Dis 2005; 5: 296-304. 
5 Bialek SR, Terrault NA. The changing epidemiology and natural history of hepatitis $\mathrm{C}$ virus infection. Clin Liver Dis 2006; 10: 697-715.

6 Poynard T, Bedossa P, Opolon P. Natural history of liver fibrosis progression in patients with chronic hepatitis C. Lancet 1997; 349: 825-832.

7 Blonski W, Reddy KR. Hepatitis C virus infection and hepatocellular carcinoma. Clin Liver Dis 2008; 12: 661-674.

8 Kawai $\mathrm{T}$, Akira S. Innate immune recognition of viral infection. Nat Immunol 2006; 7: 131-137.

9 Cheng G, Zhong J, Chung J, Chisari FV. Double-stranded DNA and double-stranded RNA induce a common antiviral signaling pathway in human cells. Proc Natl Acad Sci USA 2007; 104: 9035-9040.

10 Szabo G, Dolganiuc A, Mandrekar P. Pattern recognition receptors: a contemporary view on liver diseases. Hepatology 2006; 44: 287-298.

11 Saito T, Owen DM, Jiang F, Marcotrigiano J, Gale Jr M. Innate immunity induced by composition-dependent RIG-I recognition of hepatitis C virus RNA. Nature 2008; 454: 523-527.

12 Kanto T, Hayashi N. Innate immunity in hepatitis $C$ virus infection: Interplay among dendritic cells, natural killer cells and natural killer T cells. Hepatol Res 2007; 37 (Suppl 3): S319-S326.

13 National Institute of Health U.S.A. NIH consensus statement on management of hepatitis C. NIH Consens State Sci Statements 2002; 19: 1-46.

14 Thomas DL, Astemborski J, Rai RM, Anania FA, Schaeffer M, Galai $\mathrm{N}$ et al. The natural history of hepatitis $\mathrm{C}$ virus infection: host, viral, and environmental factors. JAMA 2000; 284: 450-456.

15 Lechner F, Wong DKH, Dunbar PR, Chapman R, Chung RT, Dohrenwend $\mathrm{P}$ et al. Analysis of successful immune responses in persons infected with hepatitis C virus. J Exp Med 2000; 191: 1499-1512.

16 Thimme R, Lohmann V, Weber F. A target on the move: innate and adaptive immune escape strategies of hepatitis $C$ virus. Antiviral Res 2006; 69: 129-141.

17 Missale G, Cariani E, Ferrari C. Role of viral and host factors in HCV persistence: which lesson for therapeutic and preventive strategies? Dig Liver Dis 2004; 36: 703-711.

18 Szabo G, Dolganiuc A. Hepatitis C and innate immunity: recent advances. Clin Liver Dis 2008; 12: 675-692.

19 Rehermann B. Hepatitis C virus versus innate and adaptive immune responses: a tale of coevolution and coexistence. I Clin Invest 2009; 119: 1745-1754.

20 Kotenko SV, Gallagher G, Baurin VV, Lewis-Antes A, Shen M, Shah NK et al. IFN-lambdas mediate antiviral protection through a distinct class II cytokine receptor complex. Nat Immunol 2003; 4: 69-77.

$21 \mathrm{Li} \mathrm{M}$, Liu X, Zhou Y, Su SB. Interferon-lambdas: the modulators of antivirus, antitumor, and immune responses. J Leukoc Biol 2009; 86: 23-32.

22 Coccia EM, Severa M, Giacomini E, Monneron D, Remoli ME, Julkunen I et al. Viral infection and Toll-like receptor agonists induce a differential expression of type I and lambda interferons in human plasmacytoid and monocyte-derived dendritic cells. Eur J Immunol 2004; 34: 796-805.

23 Ank N, West H, Bartholdy C, Thomsen AR, Paludan SR. Lambda interferon (IFN-lambda), a type III IFN, is induced by viruses and IFNs and displays potent antiviral activity against select virus infections in vivo. J Virol 2006; 80: 4501-4509.

24 Dellgren C, Gad HH, Hamming OJ, Melchjorsen J, Hartmann R. Human interferon-lambda3 is a potent member of the type III interferon family. Genes Immun 2009; 10: 125-131.

25 Ge D, Fellay J, Thompson AJ, Simon JS, Shianna KV, Urban TJ et al. Genetic variation in IL28B predicts hepatitis C treatmentinduced viral clearance. Nature 2009; 461: 399-401.

26 Suppiah V, Moldovan M, Ahlenstiel G, Berg T, Weltman M, Abate ML et al. IL28B is associated with response to chronic hepatitis $\mathrm{C}$ interferon-alpha and ribavirin therapy. Nat Genet 2009; 41: 1100-1104.

27 Tanaka Y, Nishida N, Sugiyama M, Kurosaki M, Matsuura K, Sakamoto N et al. Genome-wide association of IL28B with response to pegylated interferon-alpha and ribavirin therapy for chronic hepatitis C. Nat Genet 2009; 10: 1105-1109.

28 Rauch A, Kutalik Z, Descombes P, Cai T, Di Iulio J, Mueller T et al. Genetic variation in IL28B is associated with chronic hepatitis $\mathrm{C}$ and treatment failure-a genome-wide association study. Gastroenteroloy 2010; 138: 1338-1345.

29 Thomas DL, Thio CL, Martin MP, Qi Y, Ge D, O’Huigin C et al. Genetic variation in IL28B and spontaneous clearance of hepatitis C virus. Nature 2009; 461: 798-801.

30 Lloyd AR, Jagger E, Post JJ, Crooks LA, Rawlinson WD, Hahn YS et al. Host and viral factors in the immunopathogenesis of primary hepatitis C virus infection. Immunol Cell Biol 2007; 85: 24-32.

31 Rehermann B, Nascimbeni M. Immunology of hepatitis B virus and hepatitis C virus infection. Nature Rev Immunol 2005; 5: $215-229$.

32 Gale Jr M, Foy EM. Evasion of intracellular host defense by hepatitis C virus. Nature 2005; 436: 939-945.

33 Hiroishi K, Ito T, Imawari M. Immune responses in hepatitis C virus infection and mechanisms of hepatitis $C$ virus persistence. J Gastroenterol Hepatol 2008; 23: 1473-1482.

34 Gad HH, Dellgren C, Hamming OJ, Vends S, Paludan SR, Hartmann R. Interferon-lambda is functionally an interferon but structurally related to the interleukin-10 family. J Biol Chem 2009; 284: 20869-20875.

35 Marcello T, Grakoui A, Barba-Spaeth G, Machlin ES, Kotenko SV, MacDonald MR et al. Interferons alpha and lambda inhibit hepatitis $C$ virus replication with distinct signal transduction and gene regulation kinetics. Gastroenterology 2006; 131: 1887-1898.

36 Robek MD, Boyd BS, Chisari FV. Lambda interferon inhibits hepatitis B and C virus replication. J Virol 2005; 79: 3851-3854.

37 Zhu H, Butera M, Nelson DR, Liu C. Novel type I interferon IL-28A suppresses hepatitis C viral RNA replication. Virol J 2005; $2: 80$

38 Pagliaccetti NE, Eduardo R, Kleinstein SH, Mu XJ, Bandi P, Robek MD. Interleukin-29 functions cooperatively with interferon to induce antiviral gene expression and inhibit hepatitis C virus replication. J Biol Chem 2008; 283: 30079-30089.

39 Ank N, Iversen MB, Bartholdy C, Staeheli P, Hartmann R, Jensen UB et al. An important role for type III interferon (IFNlambda/IL-28) in TLR-induced antiviral activity. J Immunol 2008; 180: 2474-2485.

40 Taylor MW, Tsukahara T, Brodsky L, Schaley J, Sanda C, Stephens MJ et al. Changes in gene expression during pegylated interferon and ribavirin therapy of chronic hepatitis $C$ virus distinguish responders from nonresponders to antiviral therapy. J Virol 2007; 81: 3391-3401.

41 Sarasin-Filipowicz M, Oakeley EJ, Duong FH, Christen V, Terracciano L, Filipowicz $\mathrm{W}$ et al. Interferon signaling and treatment outcome in chronic hepatitis C. Proc Natl Acad Sci USA 2008; 105: 7034-7039.

42 Feld JJ, Nanda S, Huang Y, Chen W, Cam M, Pusek SN et al. Hepatic gene expression during treatment with peginterferon and ribavirin: Identifying molecular pathways for treatment response. Hepatology 2007; 46: 1548-1563.

43 Welzel TM, Morgan TR, Bonkovsky HL, Naishadham D, Pfeiffer $\mathrm{RM}$, Wright EC et al. Variants in interferon-alpha pathway genes and response to pegylated interferon-Alpha2a plus ribavirin for treatment of chronic hepatitis $C$ virus infection in the hepatitis $C$ antiviral long-term treatment against cirrhosis trial. HALT-C Trial Group. Hepatology 2009; 49: 1847-1858.

$44 \mathrm{Su} \mathrm{X}$, Yee LJ, Im K, Rhodes SL, Tang Y, Tong X et al. Association of single nucleotide polymorphisms in interferon signaling pathway genes and interferon-stimulated genes with the response to interferon therapy for chronic hepatitis C. Virahep-C Study Group. J Hepatol 2008; 49: 184-191. 
45 Chen L, Sun J, Meng L, Heathcote J, Edwards AM, McGilvray ID. ISG15, a ubiquitin-like interferon-stimulated gene, promotes hepatitis $\mathrm{C}$ virus production in vitro: implications for chronic infection and response to treatment. J Gen Virol 2010; 91: 382-388.

46 Ebihara T, Shingai M, Matsumoto M, Wakita T, Seya T. Hepatitis $C$ virus-infected hepatocytes extrinsically modulate dendritic cell maturation to activate $\mathrm{T}$ cells and natural killer cells. Hepatology 2008; 48: 48-58.

47 Decalf J, Fernandes S, Longman R, Ahloulay M, Audat F Lefrerre $\mathrm{F}$ et al. Plasmacytoid dendritic cells initiate a complex chemokine and cytokine network and are a viable drug target in chronic HCV patients. J Exp Med 2007; 204: 2423-2437.

48 Megjugorac NJ, Gallagher GE, Gallagher G. Modulation of human plasmacytoid DC function by IFN- \\{lambda $\backslash\} 1$ (IL29). J Leukoc Biol 2009; 86: 1359-1363.

49 Jordan WJ, Eskdale J, Srinivas S, Pekarek V, Kelner D, Rodia M et al. Human interferon lambda-1 (IFN-lambda1/IL-29) modulates the Th1/Th2 response. Genes Immun 2007; 8: 254-261.

50 Srinivas S, Dai J, Eskdale J, Gallagher GE, Megjugorac NJ, Gallagher G. Interferon-lambda1 (interleukin-29) preferentially down-regulates interleukin-13 over other T helper type 2 cytokine responses in vitro. Immunology 2008; 125: 492-502.

51 Mennechet FJ, Uzé G. Interferon-lambda-treated dendritic cells specifically induce proliferation of FOXP3-expressing suppressor T cells. Blood 2006; 107: 4417-4423.

52 Morrow MP, Pankhong P, Laddy DJ, Schoenly KA, Yan J, Cisper $\mathrm{N}$ et al. Comparative ability of IL-12 and IL-28B to regulate Treg populations and enhance adaptive cellular immunity. Blood 2009; 113: 5868-5877.

53 Doyle SE, Schreckhise H, Khuu-Duong K, Henderson K, Rosler R, Storey $\mathrm{H}$ et al. Interleukin-29 uses a type 1 interferonlike program to promote antiviral responses in human hepatocytes. Hepatology 2006; 44: 896-906.
54 Sommereyns C, Paul S, Staeheli P, Michiels T. IFN-lambda (IFN-lambda) is expressed in a tissue-dependent fashion and primarily acts on epithelial cells in vivo. PLoS Pathog 2008; 4: e1000017.

55 Jeffers LJ, Cassidy W, Howell CD, Hu S, Reddy KR. Peginterferon alfa-2a $(40 \mathrm{kd})$ and ribavirin for black American patients with chronic HCV genotype 1. Hepatology 2004; 39: 1702-1708.

56 Muir AJ, Bornstein JD, Killenberg PG. Peginterferon alfa-2b and ribavirin for the treatment of chronic hepatitis $\mathrm{C}$ in blacks and non-Hispanic whites. N Engl J Med 2004; 350: 2265-2271.

57 Missiha S, Heathcote J, Arenovich T, Khan K. Impact of Asian race on response to combination therapy with peginterferon alfa-2a and ribavirin in chronic hepatitis C. Am J Gastroenterol 2007; 102: 2181-2188.

58 Liu CH, Liu CJ, Lin CL, Liang CC, Hsu SJ, Yang SS et al. Pegylated interferon-alpha-2a plus ribavirin for treatmentnaïve Asian patients with hepatitis $C$ virus genotype 1 infection: a multicenter, randomized controlled trial. Clin Infect Dis 2008; 47: 1260-1269.

59 Ueda T, Chung H, Kudo M, Kitai S, Ishikawa E, Yada N et al. Prolonged PEG-IFN and RBV is effective in patients with HCV genotype 1 and high viral load who achieved virological response later than 24 weeks. Intervirology 2010; 53: 55-59.

60 Chen JY, Wang CM, Ma CC, Luo SF, Edberg JC, Kimberly RP et al. Association of a transmembrane polymorphism of Fcgamma receptor IIb (FCGR2B) with systemic lupus erythematosus in Taiwanese patients. Arthritis Rheum 2006; 54: 3908-3917.

(c) This work is licensed under the Creative Commons Attribution-NonCommercial-Share Alike 3.0 Unported License. To view a copy of this license, visit http://creativecommons.org/licenses/by-nc-sa/3.0/ 